\title{
Role Electronic Management in Achieving the Entrepreneurial Orientation in Organizations
}

\author{
Huda Hakki Majid, Assistant Prof .Aliya Jwad Mohammd Ali \\ Baghdad University - College of Administration and Economic
}

DOI: $10.37648 /$ ijrssh.v10i03.031

Received: 20 $0^{\text {th }}$ June, 2020; Accepted: 21st July, 2020; Published: $18^{\text {th }}$ August,2020

\begin{abstract}
The current research deals with identifying theeffect of the application of electronic management in achieving theentrepreneurial orientation of organizations. The Ministry of Construction, Housing, Municipalities, and Public Works has been chosen as a community for research because it is responsible for providing the necessary services to citizens and for the degradation of the services provided, It was necessary to find a way to help the ministry in reaching entrepreneurial From here were the questions of the research problem: Does the application of electronic management affect the achievement of leadership in the ministry and the possibility of electronic management in achieving the entrepreneurial orientation.The importance of the research was to clarify the important role that electronic management plays in achieving the entrepreneurial orientation of the organization in a way that makes it capable of facing the changes of the external environment and alerting the higher management to the importance of applying electronic management in order to benefit from it in achieving the organization's goals and developing its performance.The questionnaire was adopted as a tool to collect data, and two main hypotheses were formulated and sub-hypotheses branched through which the following conclusions were reached that the application of electronic management contributes to achieving creativity and that includes openness and the use of new knowledge such as technology and it turns out that the ministry is weak in providing the necessary infrastructure For the application of electronic management, as it was limited to electronic devices, and linking the departments of the Ministry with the Internet to exchange information and data electronically. The research presented a set of recommendations, the most important of which is emphasizing the use of electronic management in all departments of the ministry, especially as they are service departments, which contributes to achieving customer satisfaction and improving the performance of the ministry and the need for higher management attention to enhance the dimensions of the entrepreneurial orientation, especially after (creative and proactive) Because it has a role in achieving the ministry's goals.

Key words: electronic management, entrepreneurial orientation.
\end{abstract}

\section{INTRODUCTION}

The world has witnessed tremendous developments in all areas, especially in the technological field, which is the basis for the development of various other fields. Despite this development, most organizations, whether in the public or private sector, are not keeping pace with this development, so they should use new management methods to keep pace with this technological development, and among these methods is electronic managementWhich contributes to improving organizational flexibility, reducing costs and directing production according to the needs of the customer, which helps in achieving the entrepreneurial orientation of organizations, which contributes to raising the level of their 
performance and making them more effective by adopting administrative methods that return to achieving the goals of the organization and obtaining a competitive advantage And access to customer satisfaction.

\section{METHODOLOGY}

\section{2-1 Research problem}

The research problem lies in the following questions:

1- Is there a link between electronic management and entrepreneurial orientation?

2- Does the application of electronic management affect the achievement of leadership in the Ministry of Construction and Housing, municipalities and public works?

3- What is the possibility of electronic management in achieving the entrepreneurial orientation?

4- Does the higher management have the ability and seriousness to apply electronic management in order to achieve entrepreneurial?

5- What is the level of application of electronic administration in the Ministry of Construction, Housing, Municipalities and Public Works at the present time?

6- Does the higher management of the research organization pay sufficient attention to the entrepreneurial orientation?

\section{2-2 The importance of research}

Electronic management and entrepreneurial orientation are among the important and vital issues that organizations that want to achieve excellence and entrepreneurial must be interested in. From here the importance of research is clear:

1- Explain the important role that electronic management has in achieving the entrepreneurial orientation of the organization in a way that makes it capable of facing the changes of the external environment.

2- Alerting the higher management to the importance of applying electronic management in order to benefit from it in achieving the organization's goals and developing its performance.

3- Providing a knowledge contribution in the field of electronic management, entrepreneurial orientation and the relationship between them within a theoretical and practical framework.

4- Identify the extent of the application of electronic management in the researched organization from the viewpoint of the research sample.

\section{2-3Research Objectives}

1- Defining the role of electronic management in achieving the entrepreneurial orientation in the researched organization.

2- Knowing the Ministry's direction towards electronic management and its applicability.

3- Knowing the concept of electronic management and showing its importance and ability to positively influence management functions.

4- Knowing the available components to implement the electronic administration in the ministry.

\section{2-4Research hypothesis}

In order to achieve the objectives of the research, a set of main and subsidiary hypotheses have been formulated as follows:

1- The first main hypothesis: there is a significant correlation between electronic management and the dimensions of the entrepreneurial orientation, and this hypothesis is divided into sub-hypotheses:

A- There is a significant correlation between electronic management and innovativeness. 
B- There is a significant correlation between electronic management and accepting risk.

C- There is a significant correlation between electronic management and proactiveness.

D- There is a significant correlation between electronic management and aggressiveness.

2- The second main hypothesis: There is a significant influence between electronic management and the dimensions of the entrepreneurial orientation.

\section{2-5 Search limits}

1- Spatial boundaries: The spatial boundaries for thesearch are represented in the general directorates of the Ministry of Housing and Construction, Municipalities and Public Works (General Directorate of Municipalities, General Directorate of Sewage, General Directorate of Water, General Directorate of Planning and Follow-up, General Directorate of Urban Planning, General Directorate of Human Resources)

2- Time limits: The period starts from collecting data, completing the theoretical and practical framework for studying and coming up with conclusions and recommendations, and starts from 10/6/2020 - 7/27/2020.

2-6 Community and research sample

An intentional sample of managers from the higher, middle and lower departments in the Ministry of Construction, Housing, Municipalities and Public Works was relied upon as a research community to ensure accurate and reliable results. (75) questionnaires were distributed to the surveyed sample, and the number of questionnaires received and answered (60) was a questionnaire.
The topic of the research and its goals that it seeks to achieve plays a direct role in choosing the research method, and from looking at previous studies, the researcher relied on the descriptive analytical approach because he describes the phenomenon and explains its causes and the factors that control it .

\section{PREVIOUS STUDIES}

3-1Previous studies related to electronic management

- Study (Alkhasabah, 2017) The study aimed to identify the reality of the use of electronic management and its impact on job performance in Tafila Technical University. A questionnaire was designed and developed to collect data and distribute it to the sample units of (260) employees working in the Communications Unit. The study concluded that the level of application of electronic management was high and that there is a statistically significant effect in the use of electronic management on job performance, and that the dimensions of electronic management explain $(3.58 \%)$ of the variance in job performance.

3-2 Previous studies related to entrepreneurial orientation.

- Study (Yang \&Feng ,2017)The studyexplains to Product quality partly mediates the relationship between the entrepreneurial orientation and the organization's performance. The dimensions of the entrepreneurial orientation (innovativeness, accepting risk, proactiveness) increase the quality of the product, while (aggressiveness and competitive offensive) it has a negative relationship that is inversely proportional to product quality.The sample was a group of companies specialized in games, software, and home appliances in China, and the sample was 153 companies. Among the conclusions that the relationship between the dimensions of the entrepreneurial orientation and the quality of the product is not uniform and non-linear. Independence and creativity are among the most important dimensions of the entrepreneurial 
orientation affecting product quality, as their high levels produce high-quality products.

\section{THEORETICAL FRAMEWORK}

\section{4-1 Electronic Management}

\section{4-1-1 The concept of electronic management}

It is the administration that uses the Internet, information technology and other communication systems by integrating the organization's operations with the applications of this technology, with the aim of improving the quality of performance and achieving efficiency and effectiveness of the organization(Forman, 2014:2).Strategic approach to managing dynamic and future organizations through implementing a high-performance technology system

It focuses on automation, integration and artificial intelligence, using rapid and systematic development towards creating a knowledge environment to achieve the vision of the organization(Yao et. al, 2011: 65).Electronic management is a concept and a system consisting of functions and activities that depend in their work on the Internet to achieve pre-defined goals (Ellatif\& Ahmed, 2013: 33).Electronic management is considered an umbrella for many e-business models, and includes tools for transparent information exchange and online cooperation between the various stakeholders in the supply chain,Electronic management also includes the processes that ensure business and information technology compatibility with each other in a way that they are able to provide quality serviceand they are available, in addition to the security and performance required for electronic business success(Seresht et al., 2008: 3).It includes the use of communication and information technology in order to improve the administrative and business processes within the departments and divisions of the educational organization (Batta, et al, 2012).
4-2Entrepreneurial orientation

4-2-1 The concept of entrepreneurial

The term entrepreneurial spread in the eighteenth century and it has moved towards economic resources in terms of production and profit maximization, entrepreneurial has been taught in American business schools(Mokaya et.al,2012:130).Procedures and applications derived from participation in the product market the possibility of adopting ventures that are somewhat risky, and achieving proactive innovations directed against competitors (Campos,et.al,2012:62).It is the participation of organizations in engaging in the creation of new and advanced products for the market(Zhou,2014:36).

\section{4-2-2The concept of entrepreneurial orientation}

The entrepreneurial orientation has been receiving increased interest in recent conceptual and experimental terms and it became one of the main topics in the field of leadership and strategic management.The entrepreneurial orientation includes policies and practices that contribute mainly to taking entrepreneurial decisions and appropriate actions Including developing strategies and operations aimed at developing access to projects for the organization(Muchiri 2013: 4).The orientation is related to the organization's vision and mission, strategies, goals, organizational structure, processes and the overall organizational culture(Venter,2014:37). Entrepreneurial orientation is among the most important means that contribute to helping organizations excel and overcome the challenges they face(Gitau,et.al,2015:246).It is demonstrating the organizations' ability to innovate and work to create opportunities (Sen, 2014: 115).It is the direction of the company to try to reach new opportunities and preserving the current markets and the tendency of the organization towards the ability to show the dynamism of marketing and its ability to respond to market changes,take risks andIntroducing the required improvements and preserving the social values that make the organization eligible for innovation, learning and obtaining a competitive advantage (Tutar, et.al, 2015: 711).The effective strategic location of the organization, linked to proactivity, creativity and the 
desire to invest in high-risk projects (Shirokova et.al, 2015: 9).

4-2-3The importance of the entrepreneurial orientation

The entrepreneurial orientation is of great importance by pushing the organization to find new paths to achieve entrepreneurial and thus achieve goals and improve organizational performance. Among the most important reasons that made organizations more interested in the entrepreneurial trend are the following:

1- Increasing the ability of organizations to discover new opportunities and seize them to enhance and develop competitive advantage, as it helps them to overcome the difficulties they face in a dynamic environment characterized by scarcity of access to opportunities and limited resources(Ambad\&Wahad,2013:97).

2- It enhances the value of creativity, utilization of the skills of employees, and enhances the organizational culture that encourages improvement of performance and crystallization of new perceptions among leaders of organizations to endorse the entrepreneurialorientation and reduce conflicts arising in the organization(Shah\&Bhutta,2013:79).

3- Achieving high profits with the availability of resources that help to create new products and services aimed at obtaining a large market share, searching for new markets and investing the opportunities that arise from changes in the competitive environment(Ofem,2014:10).

4-2-4 Dimensions of the entrepreneurial orientation Studies and research have dealt with many dimensions of the entrepreneurial orientation, and one of the most common and used (innovativeness,accepting risk ,proactiveness ,aggressiveness) and which can be listed as follows:

A-innovativeness

innovativeness is introducing something new to the organization as a product, process, technology, strategy, or even management practices (
Piechowski,2010:11).innovativeness is an important aspect that focuses on the basic elements that contribute to the design of new products, the availability of the resources allocated to them, and it is used by the higher management as it is able to provide the appropriate environment to achieve creativity and excel over competitors(Freiling\&Schelhowe,2014:177).Particip ation in supporting new ideas that create new products and services and that this trend allows organizations to create a group of leadership capabilities which includes creating opportunities for creativity and directing them towards competitive business environmentsIn order to gain a competitive advantage, creativity must have an important impact on all areas of business (Perlines\&Araque, 2015: 4).

B- accepting risk accepting risk indicates a desire to venture into the unknown without expecting resultsIncluding investment in technology or entering unknown or previously tested markets, in addition to the financial risks that may affect the company (Alderman, 2011: 12).risk means the ability to understand the state of uncertainty and ambiguity and bear responsibility and burdens in the future (Bagheri\&Pihie, 2011: 452).

C- proactiveness

Proactive is the process of meeting future needs such as introducing new products and acquiring the brand that sets it apart in the market and determining future consumer demands and implemented in the current situation(Beliaeva,2014:18).proactiveness is a behavior followed by the organization that is reflected in its current activities to invest opportunities to be a leader in its field and not an affiliate(Tirfe,2014:135).

\section{D-aggressiveness}

aggressiveness ability of the company to achieve better performance than the competitors by entering the market strongly and quickly by reducing prices to a minimum, obtaining a greater market share benefit 
from the methods used by competitors and their knowledge to overcome them and reach goals (Nazri et.al, 2015: 85).It's those efforts by the organization to improve its competitive position and able to respond in terms of confrontation or interactive action(Abuya,2016:17).The strength of the organizations' efforts to hit the competitors in the market can be visualized as a strong reaction that results in intense and multiple attacks by using various strategies that depend on the productive capabilities of the organization and the extent of its investment of the opportunities available in the market(Alembummah, 2016: 37)

\section{PRACTICAL FRAMEWORK}

5-1 Presentation and analysis of the relationship of electronic management and the entrepreneurial orientation.

To identify the correlational relationship between research variables (the independent variable) represented by the electronic management variable with the (dependent variable) represented by the entrepreneurial orientation variable and consisting of the dimensions (innovativeness, accepting risk, proactiveness, aggressiveness), where the simple correlation coefficient was used to test the correlation relationship between the variables .The results were as follows:

To test the first main research hypothesis (there is a significant correlation relationship between electronic management and the dimensions of the entrepreneurial orientation) and through Table No. (1) we note:

Table (1) shows the results of the correlation between electronic management and the dimensions of the entrepreneurial orientation

\begin{tabular}{|l|l|}
\hline dependent variable & \\
dimensions of the entrepreneurial orientation & $\mathrm{r}$ \\
\hline innovativeness & 0.479 \\
\hline accepting risk & 0.414 \\
\hline proactiveness & 0.451 \\
\hline aggressiveness & 0.366 \\
\hline entrepreneurial orientation & 0.634 \\
\hline
\end{tabular}

- The value of the correlation coefficient between electronic management and innovativeness is(0.479), which is a positive andsignificant value and this means that there is a direct correlation with a significant significance between electronic management and innovativeness.
- The value of the correlation coefficient between electronic management andaccepting risk is (0.414), which is a positive and significant value, and this means that there is a direct correlation with a significant significance between electronic management and acceptingrisk.

- The value of the correlation coefficient between electronic management andproactiveness is 
(0.451), which is a positive and significant value, and this means that there is a direct correlation with a significant significance between electronic management and proactiveness.

- The value of the correlation coefficient between electronic management and aggressiveness is (0.366), which is a positive and significant value, and this means that there is a direct correlation with a significant significance between electronic management and aggressiveness .

- The value of the correlation coefficient between electronic management and the entrepreneurial orientationis (0.634), which means that there is a direct correlation with a significant significance between electronic management and the entrepreneurial orientation.

Thus, the first major hypothesis was proven.
5-2Presentation and analysis of the impact of electronic management and entrepreneurial orientation.

There is an effect of electronic management on the entrepreneurial orientation, the calculated value of $F$ reached $(15,079)$, which is greater than its tabular value at the level of significance $(0.05)$ and the degree of freedom (1.59), which is (4.0).since the sign of the beta factor is positive, this means that the effect Positive, and the value of the determination coefficient was (0.402), which means that changing one unit in electronic management will be explained by $(40.2 \%)$ of the entrepreneurial orientation, and the value of the beta coefficient $(0.459)$ is a positive value, which means when changing one unit in the electronic management will There will be an increase of $(45.9 \%)$ in the entrepreneurial orientation, as in the following table (2):

Table No. (2) shows the results of the impact of electronic management with the entrepreneurial orientation

\begin{tabular}{|c|c|c|c|c|}
\hline \multicolumn{4}{|c|}{ electronic management } & \\
\hline $\begin{array}{l}\text { the coefficient of } \\
\text { determination }\end{array}$ & $\begin{array}{l}\text { The tabular } \mathrm{F} \\
\text { value }\end{array}$ & $\begin{array}{l}\text { The computed } \mathrm{F} \\
\text { value }\end{array}$ & Beta coefficient & \\
\hline 0.402 & 4.00 & 15.079 & 0.459 & $\begin{array}{ll}\text { the } & \text { entrepreneurial } \\
\text { orientation } & \end{array}$ \\
\hline
\end{tabular}

Thus, the second major hypothesis was proven.

\section{CONCLUSIONS AND RECOMMENDATIONS}

A- Conclusions

- The application of electronic management contributes to the achievement ofinnovativeness, which includes openness and the use of new knowledge such as technology.

- The ministry is weak in providing the necessary infrastructure to implement electronic management, Where it was limited to electronic devices and linking the ministry's departments to the Internet to exchange information and data electronically.

- The results indicated that there is a significant effect of electronic management on the dimensions of the entrepreneurialorientation.

B- recommendations

- The necessity of using electronic management in all departments of the ministry, especially as it is service departments, which contributes to achieving customer satisfaction and improving the performance of the ministry. 
- The need for higher management to focus on promoting the dimensions of the entrepreneurial orientation, especially (creativity andproactiveness) because of their role in achieving the ministry's goals.

- Seeing the experiences of others in applying electronic management and benefiting from it, and working on developing employee training plans that contribute to creating the required homogeneity.

\section{REFERENCE}

1- Abuya Paul O.,( 2016),"Entrepreneurial Orientation And Performance Of Commercial Banks In Kenya",Master of Science in Entrepreneurship and Innovation Management, ,School of Business the University of Nairobi.

2- Alderman, Delton, ( 2011), "Entrepreneurial Orientation Of Eastern White Pien Primary Producers And Secondary Manufacturers: A Regional Phenomenon?"17th Central Hardwood Forest Conference .

3- Alembummah, Ananga Bernice, ,(2016),"This Thesis is Submitted to The University of Ghana, Legon in Partial Fulfilment of The Requirement for The Award of Mphil Marketing Degree ",University of Ghana.

4- Alkhasabah, M., (2017),"Reality of Use of Electronic Management and its Impact on Job Performance in Tafila Technical University", International Journal of Academic Research in Accounting, Finance and Management Sciences .Vol( 7), No(1).

5- Ambad, Sylvia Nabila Azwa, and Wahab, Kalsom Abdul, (2013) " Entrepreneurial Orientation among Large Firms in Malaysia: Contingent Australian Business Excellence.

6- Bagheri A. \& Z. A. L. Pihie, (2011), "Entrepreneurial leadership: towards a model for learning and development", Human Resource Development International, Vol( 14), Issue( 4), pp : 447-463.

7- Batta ,M et al (2012), E-Governance in E- Administration,International Journal of Computing \&Business Research.

8- Beliaeva, Tatiana,(2014)," Antecedents and Pereformance Outcomes of Entrepreneurial Orientation :A Comparative Cross - Country Study", Lappeenrata University of Technology.

9- Campos, HéctorMontiel,; Parra, José Pablo Nuño de la, and Parellada, FrancescSolé, (2012),"The Entrepreneurial Orientation-Dominant Logic-Performance Relationship in New Ventures,": an Exploratory Quantitative Study Brazilian Administration Review, Rio de Janeiro, Vol( 9), Special Issue, p.p: 60-77.

10- Ellatif, HuthaifaAbdelkarim Ali \&Ahmed,SammaniAbdulmutalib ,E-Management: Configuration, Functions and Role in Improving Performance of Arab Institutions and Organization, International Journal of Computer Applications (0975-8887), Vol.80, No.6, 2013

11- Forman Mark, (2014), E-Government Strategy, http://www.doi. gov/egovernmentDoi/pdf.

12- Freiling ,Jörg\&Schelhowe ,Christoph Lütke,(2014)," The Impact of Entrepreneurial Orientation on the Performance of Internationalization", Journal of Entrepreneurship Management and Innovation (JEMI), Volume( 10) Issue( 4),pp:169-199.

13- Gitau, Geoffrey, Mukulu, Elegwa, and Kihoro, John, (2015), " Influence of Entrepreneurial Orientation on Competitive Advantage among Mobile Servic Providers in Kenya", International Journal of Management and Commerce Innovations ISSN 2348-7585 (Online).

14- Mokaya, Samuel.,Namusonge, Mary \&Sikalieh, Damary,(2012) ，"The Concept of Entrepreneurship; in pursuit of a Universally Acceptable Definition", International Journal of Arts \& Commerce, Vol(1), No (6), PP: 128 - 135.

15- Muchiri, K; Michael, (2013), "Entrepreneurial Orientation and Leadership: A Review, Model and Research Agenda", Small Enterprise Association of Australia and New Zealand.

16- Nazri,Muhamad Azrin,et al ,(2015),"The Effect of Entrepreneurial Orientation Dimensions on Takaful Agency's BusinessPerformance in Malaysia",KesanKeusahawananOrientasiterhadapPrestasiPerniagaanAgensi Takaful di Malaysia,JurnalPengurusan ,Vol 45 ,pp83 - 94. 
17- Ofem, Brandon,(2014)," Entrepreneurial Orientation, Collaborative netwoek, and nonprofit performance ", Teses and Dissertations--Business Administration. 3, University of KentuckyUKnowledge.

18- Perlines,Felipe Hernández\&Araque,Benito Yañez,(2015),"Entrepreneurial orientation in hotel establishments",2nd International Symposium on Partial Least Squares Path Modeling, Seville (Spain).

19- PiechowskiTodd.,(2010)," Social Entrepreneurship in Texas Nonprofit Organizations" In Partial Fulfillment for the Requirements for the Degree of Masters of Public Administration.

20- Sen ,Barbara, (2014)," Multiple Strategic Orientations: The Public Library as a Societal Organization" ,3rd International Conference on Integrated Information, Procedia - Social and Behavioral Sciences Vol(147), pp:111 - 119.

21- Seresht, Hossein Rahman \&Fayyazi, Marjan\&Asl, NastaranSimar,E-management: Barriers and challenges in Iran, EowerKraklead, 2008.

22- Shah, Syed Zulfiqar Ali, and Bhutta, Nousheen Tariq, (2013), "Corporate Entrepreneurship and Agency Cost: A Theoretical Perspective", Open Journal of Accounting, Vol(2),Issue(3),pp: 79-86.

23- Shirokova, G., Bogatyreva, K., \&Beliaeva, T.,(2015),"Entrepre-neurial Orientation of Russian Firms:The Role of External Environment", Innovation and Economy, Vol( 9 ),No( 3),pp:6-25.

24- Tirfe ,Aregawi, Ghebremichael,(2014), "Entrepreneurial Orientation as Growth Predictor of Small Enterprises Evidence from Tigray Regional State of Ethiopia", Developing Country Studies www.iiste.org ISSN 2224-607X (Paper) ISSN 2225-0565 (Online), Vol(4), No(11).

25- Tutar ,hasan ,et al,(2015)" The Effects of Strategic Orientations on Innovation Capabilities and Market Performance: The Case of ASEM " , $11^{\text {th }}$ International Strategic Management Conference.

26- Venter ,JJ.,(2014),"An assessment of entrepreneurial orientation in the maintenance divisions of a South African steel manufacturer", the degree Master of Business Administration at the Potchefstroom Campus of the North-West University.

27- Yang Y.,\& Feng Ju X.,( 2017),"Entrepreneurial Orientation and Firm Performance: Is Product Quality a Missing Link?"Entrepreneurship Research Journal, Vol (8),issue(1),pp: 1-13.

28- Yao, lin , et.al.,(2011),e-management development and deployment strategy for future organization ,African journal of business management ,vol. 5, no .16 pp 657-667.

29- Zhou, Yangping,(2014)," Market Orientation and Entrepreneurial Orientation in a Learning Organization",Ludwig-Maximilians-University Aus Ningbo, Zhejiang, China. 